\title{
ĐĂC ĐIỂM TƯỚNG TRẦM TÍCH TURBIDITE TRÊN QUẦN ĐẢO CÔ TÔ, ĐÔNG BẮC VIÊTT NAM
}

\author{
Nguyễn Văn Kiểu',2, Bùi Việt Dũng', Bùi Huy Hoàng', Nguyễn Quang Tuấn' \\ 'Viện Dầu khí Việt Nam \\ ${ }^{2}$ Trường Đại học Khoa học và Công nghệ AGH, Ba Lan \\ Email: van@agh.edu.pl \\ https://doi.org/10.47800/PVJ.2021.07-01
}

\section{Tóm tắt}

Nghiên cứu trình bày các phân tích chi tiết về tướng trầm tích của hệ tầng Cô Tô phân bố trên các đảo Cô Tô To, Cô Tô Con và đảo Thanh Lân thuộc quần đảo Cô Tô, tỉnh Quảng Ninh. Tướng trầm tích từ $\mathrm{F} 1$ đến $\mathrm{F} 7$ đã được nhận diện và phân loại dựa trên thành phần, cấu trúc trầm tích, tính phân lớp và xu hướng độ hạt là bằng chứng giúp xác định môi trường lắng đọng trầm tích. Kết quả phân tích cho thấy sự phát triển lặp lại của các tướng trầm tích này trong hệ thống trầm tích turbidite trên quần đảo Cô Tô có thể được nhóm lại thành các nhóm tướng môi trường ( $\mathrm{FA}$ ): nhóm tướng sườn thềm với các kênh và trầm tích dạng trượt lở (slump) (FA1); quạt ngầm đáy biển với sự xuất hiện phổ biến của các kênh rạch đào khoét thuộc phần quạt trong (FA2); thùy quạt giữa (FA3) và thùy quạt ngoài (FA4). Các nhóm tướng này đại diện cho hệ thống trầm tích biển sâu với sự phát triển mạnh mẽ của quạt ngầm turbidite theo hướng Đông Bắc - Tây Nam, phát triển từ đảo Thanh Lân, đảo Cô Tô Con đến đảo Cô Tô To.

Từ khóa: Tướng turbidite, trầm tích nước sâu, quạt ngầm đáy biển, quần đảo Cô Tô, đảo Thanh Lân.

\section{Giới thiệu}

Nhiều vỉa dầu khí với giá trị kinh tế lớn trên thế giới đã được phát hiện tại hơn 80 bể trầm tích trong các thành tạo trầm tích turbidite [1 - 3]. Tại Việt Nam, bên cạnh các phát hiện dầu khí trong móng hay trong các thành tạo trầm tích ven bờ tuổi Oligocene và Miocene thuộc các bể trầm tích Cenozoic trên thềm lục địa Việt Nam, thì các thành tạo trầm tích turbidite hình thành trong môi trường nước sâu cũng là đối tượng gần đây được đặc biệt quan tâm. Liên quan đến các thành tạo trầm tích này có thể kể đến cụm mỏ khí Hải Thạch - Mộc Tinh của bể Nam Côn Sơn với vỉa chứa cát kết turbidite tuổi Miocene giữa và gần đây nhất là các phát hiện dầu khí trong cát kết turbidite Miocene muộn tại các giếng khoan Kèn Bầu thuộc khu vực phía Nam bể Sông Hồng.

Để hiểu rõ hơn về đặc điểm tướng, môi trường trầm tích của các thành tạo trầm tích turbidite môi trường biển sâu của các bể trầm tích chứa dầu khí trên thế giới nói chung và ở Việt Nam nói riêng, công tác nghiên cứu khảo

Ngày nhận bài: 26/5/2021. Ngày phản biện đánh giá và sửa chữa: 26/5 - 8/6/2021. Ngày bài báo được duyệt đăng: 1/7/2021. sát thực địa tại các điểm lộ trầm tích trên bờ rất được chú trọng. Các nghiên cứu phân tích chi tiết các điểm lộ liên quan đến các thành tạo trầm tích tương ứng để minh họa và đối sánh với các đặc điểm trầm tích thu thập được từ giếng khoan. Kết quả phân tích và so sánh đó kết hợp với phân tích địa vật lý là bằng chứng quan trọng để luận giải và minh họa cho điều kiện thành tạo liên quan đến các đối tượng chứa dầu khí nằm sâu trong lòng đất.

Trên lục địa và các đảo của Việt Nam, điểm lộ tiêu biểu để nghiên cứu và minh họa cho các kiểu trầm tích nước sâu phải kể đến thành tạo trầm tích turbidite thuộc hệ tầng Cô Tô phân bố trên đảo Cô Tô To (CTT), đảo Cô Tô Con (CTC) và đảo Thanh Lân (TL) thuộc quần đảo Cô Tô (Hình 1).

Nghiên cứu này đã tiến hành phân tích chi tiết tướng trầm tích của các thành tạo trầm tích turbidite phân bố trên phạm vi các đảo Cô Tô To, đảo CôTô Con và đảo Thanh Lân. Nhóm tác giả đã phân loại thạch học, nhận diện các kiểu cấu trúc trầm tích turbidite, phân chia tướng/nhóm tướng, đo hướng đổ của các cấu trúc xiên chéo và gợn sóng, đo vẽ các cột địa tầng thạch học và phục hồi quá trình lắng đọng và phát triển của hệ thống quạt ngầm đáy biển (submarine fans). 


\section{2. Địa chất khu vực nghiên cứu}

\subsection{Bối cảnh kiến tạo}

Bối cảnh kiến tạo hay môi trường địa động lực sinh thành các thành tạo turbidite hệ tầng Cô Tô hiện nay có nhiều quan điểm khác nhau: (1) được thành tạo trong một võng sụt sâu tương ứng kiểu võng sụt nội máng Caledonian muộn Đông Bắc Bắc Bộ [4]; (2) nguồn gốc từ quá trình tạo núi tái sinh và được lắng đọng trong một bồn trước cung (forearc basin) [5, 6]; (3) dạng tổ hợp thạch - kiến tạo kiểu bồn tiền địa, phản ánh quá trình tạo núi, bào mòn diễn ra trong giai đoạn Ordovician muộn - Silurian sớm (O3-S1) ở Đông Bắc Bắc Bộ [7]; (4) hình thành trong bối cảnh bể tiền địa, môi trường địa động lực "đai tạo núi nội lục"... [8]. Nhìn chung, trầm tích hệ tầng Cô Tô bị phủ bất chỉnh hợp góc bởi trầm tích lục nguyên hệ tầng Đồ Sơn (D2-3đs) và có thể quan sát rõ ở đảo Trần (hay còn gọi là đảo Lò Chúc San hoặc Chàng Tây, thuộc huyện đảo Cô Tô, tỉnh Quảng Ninh) [9]. Từ Devonian giữa đến nay, các thành tạo trầm tích của hệ tầng Cô Tô bị biến dạng mạnh liên quan đến pha tạo núi Indosinian trong Permian muộn - Triassic sớm, pha xâm nhập Yến Sơn trong Cretaceous muộn, và cuối cùng là pha kiến tạo trượt bằng trong Cenozoic vẫn còn hoạt động cho đến hiện tại [7].

\section{2. Địa tâng trầm tích}

Các thành tạo trầm tích trên đảo Cô Tô (bao gồm đảo Cô Tô To và Cô To Con) và đảo Thanh Lân được xếp vào hệ tầng Cô Tô (Hình 1). Thành tạo trầm tích này được đề cập lần đầu tiên vào năm 1892 và đã thể hiện đảo Thanh Lân trên bản đồ địa chất các bể than ở Bắc Kỳ tỷ lệ 1/4.000.000. Ban đầu thành tạo trầm tích được xếp vào hệ tầng Cô Tô với tuổi giả định Neogene dựa trên mô tả thành phần thạch học của các thành tạo trầm tích phân bố trên quần đảo Cô Tô và so sánh tương đồng với trầm tích Neogene trên đất liền [10]. Nhưng các nghiên cứu sau đó đã chỉ ra rằng hệ tầng Cô Tô có tuổi Silurian sớm thông qua một loạt các hóa thạch bút

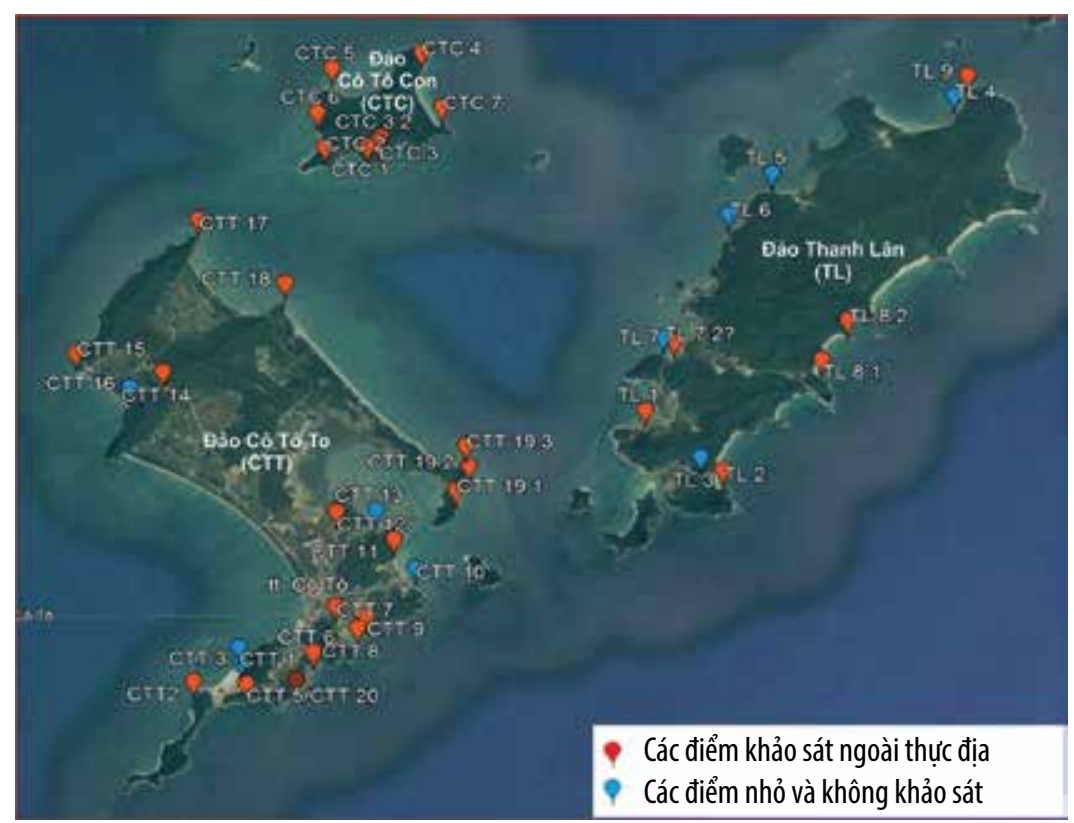

Hình 1. Bản đồ vi trí các điểm khảo sát ngoài thực đia trên đảo Cô Tô và đảo Thanh Lân, Việt Nam. đá tìm thấy ở trên các đảo Thanh Lân, Cô Tô và nhiều đảo khác [11 - 13]. Sự tồn tại của các hóa thạch bút đá này đã xác minh tuổi Silurian sớm và các thành tạo trầm tích của hệ tầng Cô Tô liên quan đến môi trường biển sâu. Trên cơ sở nghiên cứu các thành hệ địa chất và địa động lực, hệ tầng Cô Tô được xếp vào thành hệ flysch, phản ánh quá trình thành tạo trầm tích ở môi trường nước sâu trong điều kiện thu hẹp và tiêu biến biển trong giai đoạn Ordovician muộn - Silurian sớm (O3-S1) ở Đông Bắc Bắc Bộ [14]. Trong nghiên cứu và thiết lập các phân vị tầng Việt Nam, Tống Duy Thanh và Vũ Khúc cho rằng để thành tạo nên khối lượng trầm tích lớn như vậy đòi hỏi thời gian khá dài và đã xếp hệ tầng Cô Tô tương ứng với tuổi Ordovician muộn Silurian sớm [9].

\section{Cơ sở tài liệu và phương pháp nghiên cứu}

Nghiên cứu được thực hiện trên cơ sở 40 điểm khảo sát thuộc đảo Cô Tô To, đảo Cô Tô Con và Thanh Lân (Hình 1). Tại mỗi điểm lộ, nhóm tác giả đã tiến hành định vị tọa độ điểm khảo sát, quan sát, mô tả và đo vẽ ngoài thực địa. Trong nghiên cứu này, bề dày các lớp trầm tích được phân định và phân loai cỡ hat trầm tích theo tiêu chuẩn hiện hành $[15,16]$. Dựa trên các mô tả và quan sát sự phát triển theo không gian và thời gian của các kiểu trầm tích ngoài thực địa, kết hợp với phân tích thạch học từ các mẫu lấy tại các điểm lộ, các tướng thạch học và nhóm tướng tại mỗi điểm lộ đã được nhận diện theo phân loại tướng trầm tích turbidite của Shanmugam (1988) [20]. Các tướng/nhóm tướng này sau đó được thể hiện trên bản đồ dưới dạng biểu đồ hình tròn biểu diễn tỷ lệ của các tướng xuất hiện. Trong quá trình nghiên cứu ngoài thực địa, nhóm tác giả cũng tiến hành đo hướng đổ của tất cả cấu trúc xiên chéo và gợn sóng quan sát tại mỗi điểm lộ và thể hiện lên bản đồ dưới dạng biểu đồ hoa hồng để xác định hướng cung cấp vật liệu trầm tích. 


\section{Kết quả và thảo luận}

\subsection{Tướng thạch học}

Trên cơ sở các đặc trưng về cấu trúc trầm tích, kích thước hạt, bề dày lớp và thành phần trầm tích, nhóm tác giả đã phân loại các thành tạo trầm tích turbidite trên đảo Cô Tô và đảo Thanh Lân thành 7 tướng thạch học với thành phần thay đổi từ cuội tảng, cát kết đến bột sét và ký hiệu từ F1 đến F7 (Hình 2).

Tướng thạch học F1 gồm các thành tạo cát kết hạt thô đến mịn, phổ biến là các dải cát/sét uốn lượn dạng dòng chảy rối xen kẽ nhau và thỉnh thoảng có các ổ sét màu xám xanh đến xám đen. Tỷ lệ cát/sét trong tướng thạch học F1 thường là cát kết chiếm ưu thế, đôi chỗ tỷ lệ cát và sét ngang nhau. Ở một số nơi, tướng thạch học F1 chỉ xuất hiện dạng cấu trúc uốn lượn mà ít gặp các dải cát/sét uốn lượn nhưng bề dày thường nhỏ so với các tướng gặp các dải cát/sét.

Tướng thạch học F2 với thành phần chiếm ưu thế là cát, cát sạn với kích thước từ hạt thô đến mịn. Trong lớp cát, cát sạn thường bắt gặp các mảnh hoặc ổ trầm tích ngoại lai có cỡ hạt đa dạng từ sạn đến bột sét, nhưng phổ biến nhất là các ổ sét (mud clast) và đôi chỗ các ổ sét này có cấu trúc trầm tích bên trong. Cỡ hạt của ổ trầm tích ngoại lai này có quan hệ mật thiết với cỡ hạt của tập trầm tích chính. Tướng thạch học F2 thường ít gặp các kiểu vi cấu trúc trong mỗi lớp riêng biệt, đôi khi tướng này có sự phân dị cỡ hạt mịn dần từ dưới lên trên.

Tướng thạch học F3 có thành phần trầm tích khá đa dạng do liên quan đến các tướng đào khoét của các kênh dẫn (channel) với cõ̃ hạt từ cuội, sạn ở phần đáy và phía trên là cát hạt thô đến hạt trung và thỉnh thoảng bắt gặp các lớp hạt mịn phía trên. Phần dưới của tướng bắt gặp các ranh giới đào khoét rất rõ và cắt các lớp trầm tích phía dưới. Ranh giới đáy cũng phổ biến các cấu tạo ngọn lửa (flame structure) và khuôn tải trọng (load cast).

Tướng thạch học $F 4$ chủ yếu gồm cát kết với bề dày 30 - 45 cm, có khi lên tới 1 - 2 m. Bên trong các lớp cát thuộc tướng thạch học F4 gần như không quan sát được cấu trúc trầm tích, nếu có chỉ có thể quan sát được sự phân dị

Bảng 1. Đặc trưng tướng trầm tích quan sát được trên đảo Cô Tô và đảo Thanh Lân và đối sánh với phân loại của Emiliano Mutti và Ricci Lucchi [17]

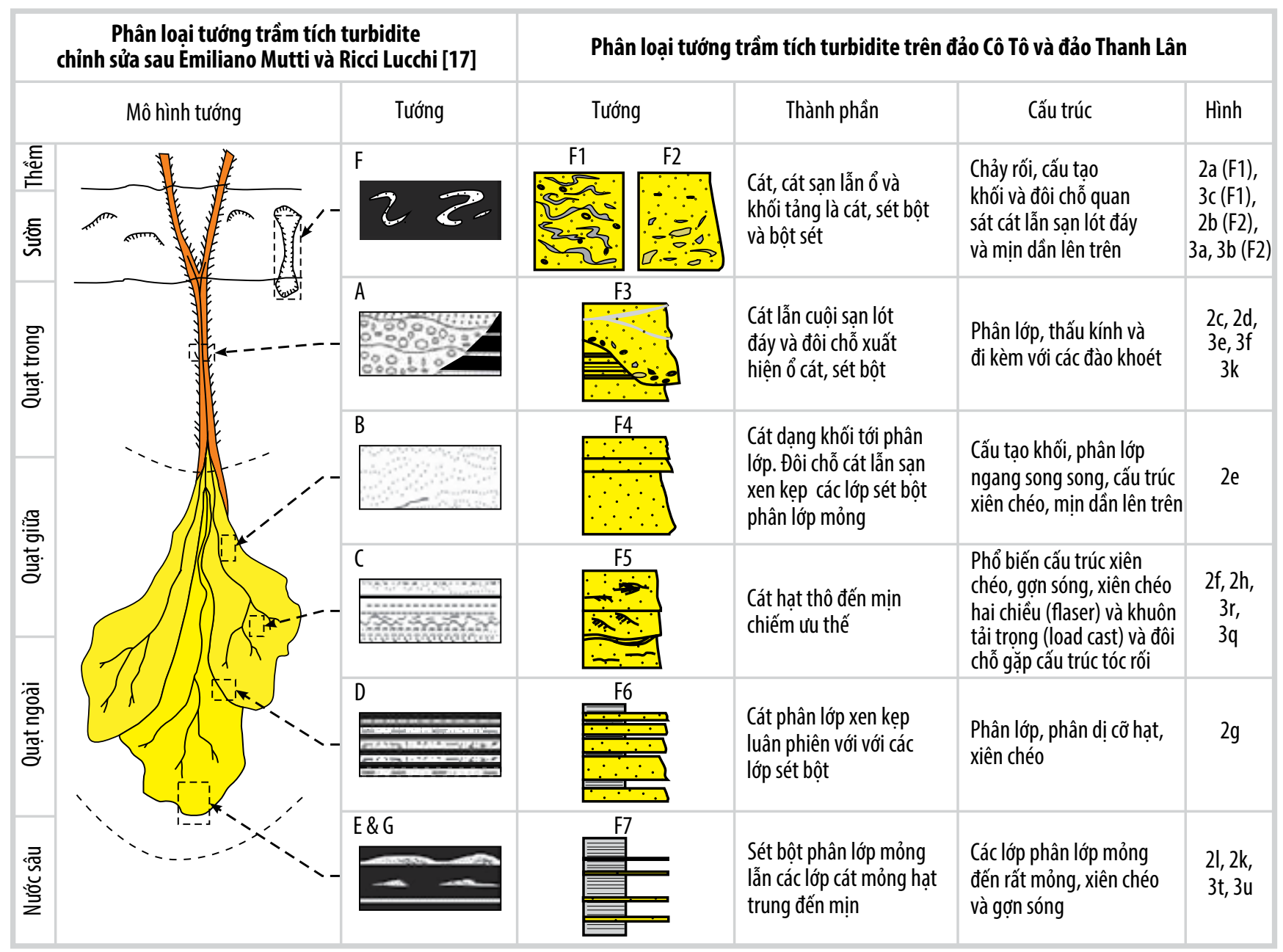


cỡ hạt ở một số điểm lộ. Tướng thạch học F4 thường gồm các lớp cát kết sắp xếp luân phiên và đôi chỗ xen kẽ các lớp sét bột phân lớp rất mỏng dưới $5 \mathrm{~cm}$.

Tướng thạch học $\mathrm{F} 5$ chủ yếu là cát hạt thô đến mịn chiếm ưu thế với bề dày $20-45 \mathrm{~cm}$ (ít gặp các lớp trầm tích dày hơn) và dễ quan sát thấy cấu trúc xiên chéo, gợn sóng và khuôn tải trọng. Thành phần trầm tích có sự phân dị cỡ hạt trong mỗi lớp trầm tích và phần chứa cát hạt trung - mịn thường chứa các cấu trúc gợn sóng. Ngoài ra, cũng bắt gặp trong tướng thạch học $\mathrm{F} 5$ các cấu trúc xiên chéo 2 chiều (flaser) và cấu trúc ngọn lửa (nhưng không phổ biến).

Tướng thạch học F6 gồm các lớp cát phân lớp ngang song song dày từ $20-50 \mathrm{~cm}$ xen kẹp các lớp sét bột phân lớp mỏng. Đôi khi bắt gặp các lớp cát có phân cấp độ hạt rõ và phần cát hạt mịn thường chứa cấu trúc gợn sóng. Kết thúc mỗi lớp cát thường là các lớp sét bột phân lớp mỏng màu xám đen và màu trắng do lớp trầm tích có tỷ lệ bột chiếm ưu thế.

Tướng thạch học F7 là các lớp sét, sét bột phân lớp mỏng $(10 \mathrm{~cm})$ đến rất mỏng $(3 \mathrm{~cm})$ xếp luân phiên và thỉnh thoảng xen kẹp các lớp cát hạt trung đến mịn với bề dày không lớn (bề dày của các lớp cát xen kẹp này thường không lớn hơn bề dày các lớp cát của tướng thạch học F6). Cấu trúc trầm tích trong các lớp này thường rất phổ biến các dạng xiên chéo và gợn sóng. Trầm tích thường có màu xám xanh đến xám đen và đôi khi gặp màu xám sáng do tỷ lệ bột chiếm ưu thế hơn so với sét.

\subsection{Nhóm tướng và môi trường trầm tích}

Dựa trên các tướng thạch học, trình tự sắp xếp của các lớp trầm tích và xu hướng phát triển cỡ hạt từ cổ đến trẻ trên mỗi cột địa tầng thạch học được xây dựng tại từng điểm khảo sát trên đảo Cô Tô và đảo Thanh Lân (Hình 4). Nghiên cứu này đã phân định thành 4 nhóm tướng (facies association - FA) từ FA1 đến FA4 tương ứng với mỗi kiểu môi trường tầm tích thay đổi từ sườn thềm đến quạt ngoài. Các nhóm tướng này tương ứng với phạm vi phân bố theo không gian và trật tự lắng đọng theo thời gian. Các đặc trưng trầm tích và các kiểu môi trường tương ứng liên quan đến 4 nhóm tướng này được mô tả chi tiết như sau:

\section{- FA1 - nhóm tướng sườn (slope)}

Nhóm tướng FA1 chủ yếu gồm các tướng $F 1, F 2$ và nhiều vị trí thường đi với cả tướng F7. Nhóm tướng này bao gồm chủ yếu là các tập cuội, cát hoặc sét bột với độ dày khác nhau có cấu trúc trượt lở hoặc ảnh hưởng của chảy rối (turbidity current). Bên trong các tập trầm tích thường có các ổ trầm tích ngoại lai với nhiều kích thước khác nhau có thể đạt đến vài chục $\mathrm{cm}$ như quan sát khá phổ biến tại các điểm lộ trên đảo Cô Tô Con (Hình 2a, b và $3 a)$. Nhìn chung, tỷ lệ sét thấp và thay vào đó là các trầm tích hạt thô chiếm ưu thế trong nhóm tướng này. Theo phân loại của Emiliano Mutti và Ricci Lucchi [17], nhóm tướng này đặc trưng cho môi trường sườn thềm lục địa, với cơ chế vận chuyển trầm tích chính là trượt lở và dòng vụn hỗn độn (slide, slump và debris flow). Trầm tích thuộc nhóm tướng này bắt nguồn từ sự bất ổn định của sườn thềm dẫn đến trượt lở và khi trầm tích được vận chuyển xuống chân sườn đã được tăng cường về năng lượng cũng như mức độ xáo trộn. Điều này cũng có thể là nguyên nhân hình thành các thành tạo trầm tích có cấu trúc hỗn độn với sự xuất hiện của các ổ cát, ổ sét và các dải cát, sét bột uốn lượn như quan sát phổ biến trên đảo Cô Tô Con (Hình 2a, b).

\section{- FA2 - nhóm tướng quạt trong (inner fan)}

Nhóm tướng FA2 gồm các tướng $F 2$, F3 và $F 4$ xếp chồng lên theo thứ tự. Trên mặt cắt của nhóm tướng FA2, trầm tích có xu thế mịn dần lên trên từ cát sạn lẫn cuội (bao gồm cả các ổ sét hoặc cát) của tướng $F 2$ đến cát sạn của tướng $\mathrm{F} 3$ lót đáy và thường kết thúc là cát hạt thô đến mịn xen các lớp bột sét rất mỏng xen kẹp giữa các lớp cát dày của tướng F6. Đồng thời, theo mặt cắt của nhóm tướng $F A 2$, càng lên phía trên các lớp cát càng mỏng dần và có tính phân lớp rõ ràng hơn. Theo phân loại môi trường, nhóm tướng này được xếp vào các thành tạo liên quan đến các kênh rạch ngầm (channel) và các tập sét mỏng phân lớp song song đặc trưng cho trầm tích hạt mịn hình thành trong điều kiện năng lượng thấp nằm hai bên kênh rạch ngầm. Nhiều nơi, có thể dễ dàng quan sát được các ranh giới đào khoét dạng kênh rạch và đáy, thường là cát hạt thô lẫn cuội sạn (Hình 2c, d). Đôi khi đáy của các lớp phổ biến cấu trúc ngọn lửa (Hình $3 \mathrm{l}, \mathrm{m}$ ) và khuôn tải trọng (Hình 3i). Theo không gian, nếu đi từ rìa tới giữa các kênh rạch, cấu trúc trầm tích sẽ có dạng thấu kính ở nơi chuyển tiếp giữa tướng F3 và F4. Trên một vài mặt cắt, đôi khi phần mỏng dưới đáy của các tập cát có xu thế thô dần lên, trước khi trở lại xu thế mịn dần lên trên. Các ổ trầm tích ngoại lai cũng bắt gặp trong nhóm tướng này nhưng kích thước của chúng và cỡ hạt trầm tích thường nhỏ hơn so với nhóm FA1, từ cát kết hạt thô lẫn sạn, cát kết tới sét bột. Nhiều nơi bắt gặp các cấu tạo xiên chéo trong các lớp cát kết với góc dốc lớn gần đạt tới $30^{\circ}$. Nhóm tướng FA2 đặc trưng cho môi trường quạt trong, đây là những kênh dẫn vật liệu trầm tích từ sườn tới các quạt. Trong môi trường 
quạt trong, nhóm tướng FA2 có thể chia thành 2 phần: (1) Phần có năng lượng cao xuất hiện trong các kênh rạch ngầm, với các mặt cắt điển hình có dạng kênh xếp chồng; (2) Phần có năng lượng thấp nằm ngoài rìa các kênh rạch, trầm tích thường mịn hơn và thường thể hiện dưới dạng thấu kính [18]. Kết quả là các lòng kênh được lấp đầy bởi các thân cát dày bắt nguồn từ các trầm tích trượt lở đổ xuống từ sườn thềm và sau khi được trộn thêm nước đã tăng tính linh động và năng lượng dòng chảy, dẫn đến khả năng đào khoét cao tại nơi chúng đi qua [19]. Emiliano Mutti cho rằng các trầm tích này có thể bắt nguồn từ các dòng turbidite có mật độ cao, năng lượng lớn có khả năng vận chuyển trầm tích hạt thô đến rất thô phân bố ở quạt trong [18].
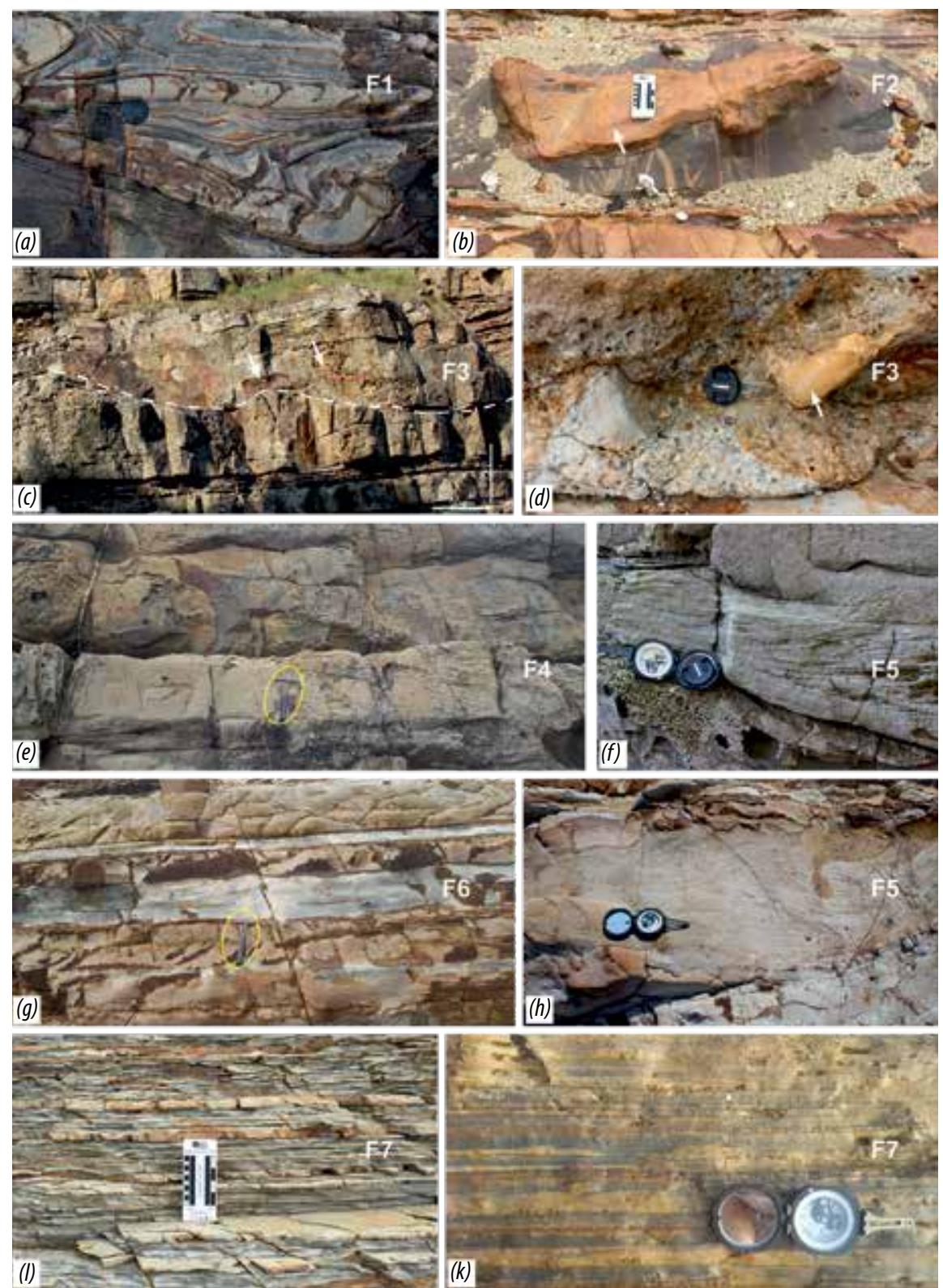

Hinh 2. Ảnh minh họa 7 tướng trâm tích quan sát được trên đảo Cô Tô và Thanh Lân (xem thêm mô tả chi tiết mỗi kiểu tướng tại Bảng 1 và Mục 4.1): (a) tướng F1 sét bột xen cát cấu trúc dạng dải uốn lượn; (b) tướng F2 các lớp cát dày chứa các khối tảng cát và ổ sét bột ngoại lai; (c, d) tướng F3 đặc trưng bởi sự có mặt của các đào khoét (c) và các tâng cuội sạn lẫn các ổ/ khối cát ngoại lai nằm trên ranh giới đào khoét (d); (e) tướng $F 4$ cát phân lớp xen các lớp sét bột phân lớp rất mỏng; $(f, h)$ tướng F5 cát kết cấu trúc phân lớp xiên chéo; (g) tướng F6 cát xen các lớp sét bột phân lớp mỏng và đôi chỗ bể dày của các sét/bột có thể đạt bề dày của các lớp cát trong tướng này; (l, k) tướng $F 7$ gồm sét, sét bột xen các lớp cát mỏng.
- FA3 - nhóm tướng quạt giữa (middle fan)

Nhóm tướng FA3 gồm các tập cát thô đến trung có thể lẫn sạn liên quan đến các tướng $F 4$ và $F 5$; đôi khi trong nhóm tướng này cũng bắt gặp cát phân lớp xen kẹp các tập cát mịn hoặc lớp sét bột với độ dày khá ổn định tương ứng với tướng F6. Nhìn tổng thể, nhóm tướng FA3 thường có xu thế mịn dần lên trên và ngay trong mỗi lớp cát của chúng cũng có thể bắt gặp sự phân dị cỡ hạt mịn dần lên trên: Phần lót đáy của nhóm tướng FA3 có thể là cát sạn hoặc cát hạt thô của tướng F4 và gần như vắng bóng cuội tảng. Các mảnh đá trôi nổi vẫn có thể bắt gặp trong nhóm tướng FA3 nhưng với kích thước nhỏ hơn rất nhiều so với nhóm tướng FA2; dịch chuyển dần lên phía trên là cát hạt mịn hơn có phân lớp xiên chéo hoặc cấu trúc gợn sóng của tướng F5. Các lớp cát xen kẹp các lớp sét bột phân lớp mỏng giống như quan sát thấy ở tướng F6. Trong nhóm tướng FA3, các cấu trúc tóc rối (convoluted structure) chỉ bắt gặp trong các trầm tích hạt mịn. Ranh giới giữa các lớp cát và sét bột vẫn quan sát được các cấu trúc ngọn lửa. Nhóm tướng FA3 đặc trưng cho môi trường quạt giữa, nơi xuất hiện các thân cát dạng lớp phủ (sheet sand) có diện phân bố rộng xen với các thân cát phân bố dọc các kênh rạch. Tỷ phần cát sét trong nhóm tướng FA3 tương đối cao và thấp hơn $F A 1$ và $F A 2$ nhưng ngược lại diện phân bố của các thân cát phát triển rất rộng. Theo không gian, sự phân bố của nhóm tướng FA3 có thể kéo dài hàng trăm mét và chịu ảnh hưởng chính từ dòng turbidite lấp đầy lòng kênh hoặc tràn bờ để tạo các thùy trầm tích (lobe) [18]. Trong cơ chế vẫn chịu ảnh hưởng của hoạt động trượt ở 

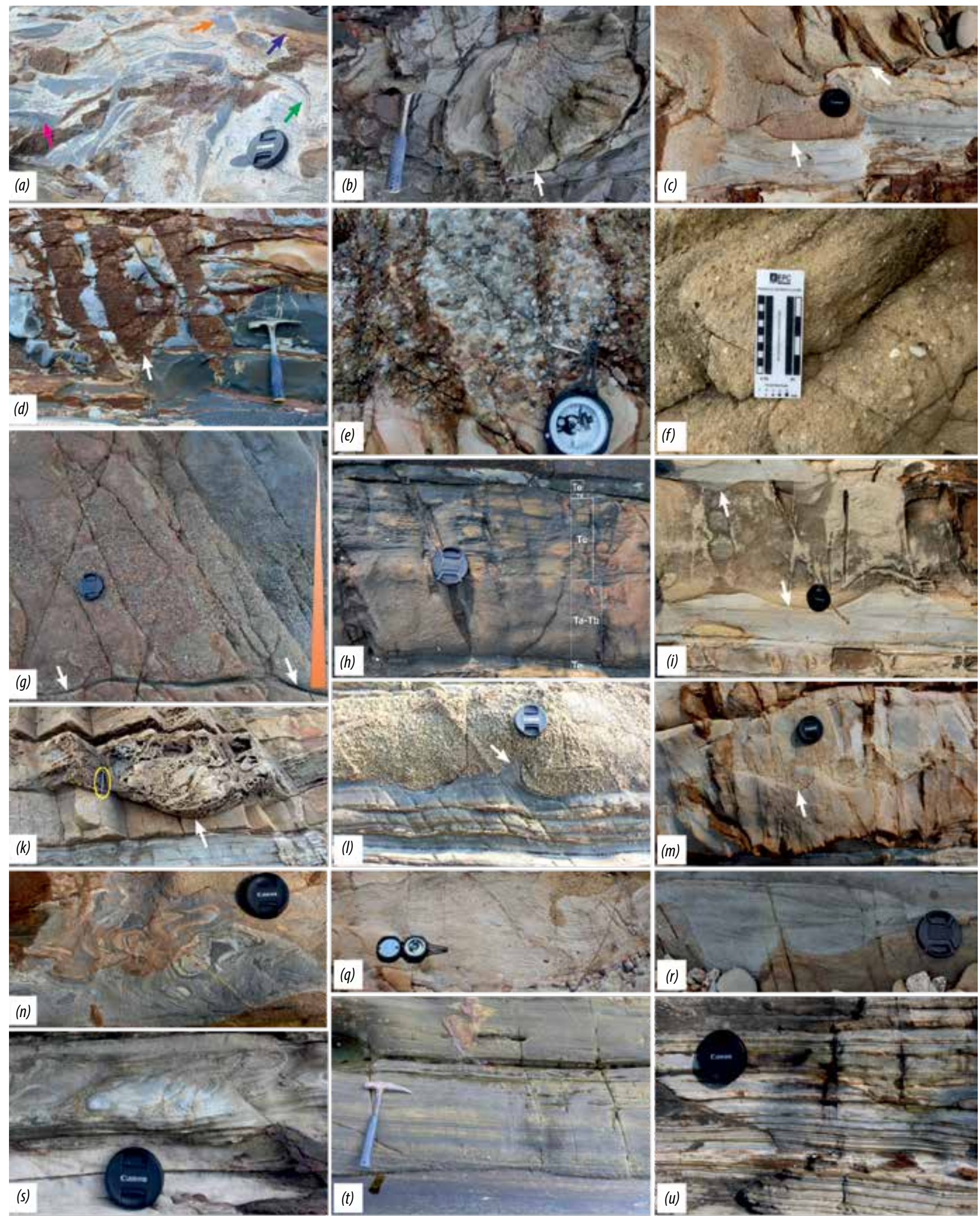

Hinh 3. Các cấu trúc trâm tích tiêu biểu quan sát được từ thành tạo trầm tích turbidite trên đảo Cô Tô và đảo Thanh Lân: (a) dòng chảy rối với các dải sét uốn lượn; (b) khối cát sạn ngoại lai nằm trong các tập cát (large pebble-sized clast); (c) các lớp cát và sét bột ngoại lai nằm trong cát hạt thô đến mịn (angular clast); (d) cát sạn tiêm nhập (injection structures); (e) sạn kết đa khoáng lót đáy các lớp cát dày; (f) cát hạt thô lẫn sạn cấu tạo khố; (g) cát sạn cấu tạo khối có sự phân dị cõ̃ hạt từ thô tới mịn với đáy của các lớp cát là các cranh giới của khuôn tải trọng; (h) tướng và cấu trúc trâm tích tương ứng với chu kỳ Bouma (Bouma sequence); (i) khuôn tải trọng (load cast); ( $k$ ) đào khoét của kênh rạch; (l, m) cấu trúc ngọn lửa (flame); (s) cấu trúc tóc rối (convolute); (q, r) cấu trúc xiên chéo và gọnn sóng (climbing ripples và wavy); (t, u) cấu trúc ngang song song và phân lớp mỏng (parallel laminated và thin bedding). 

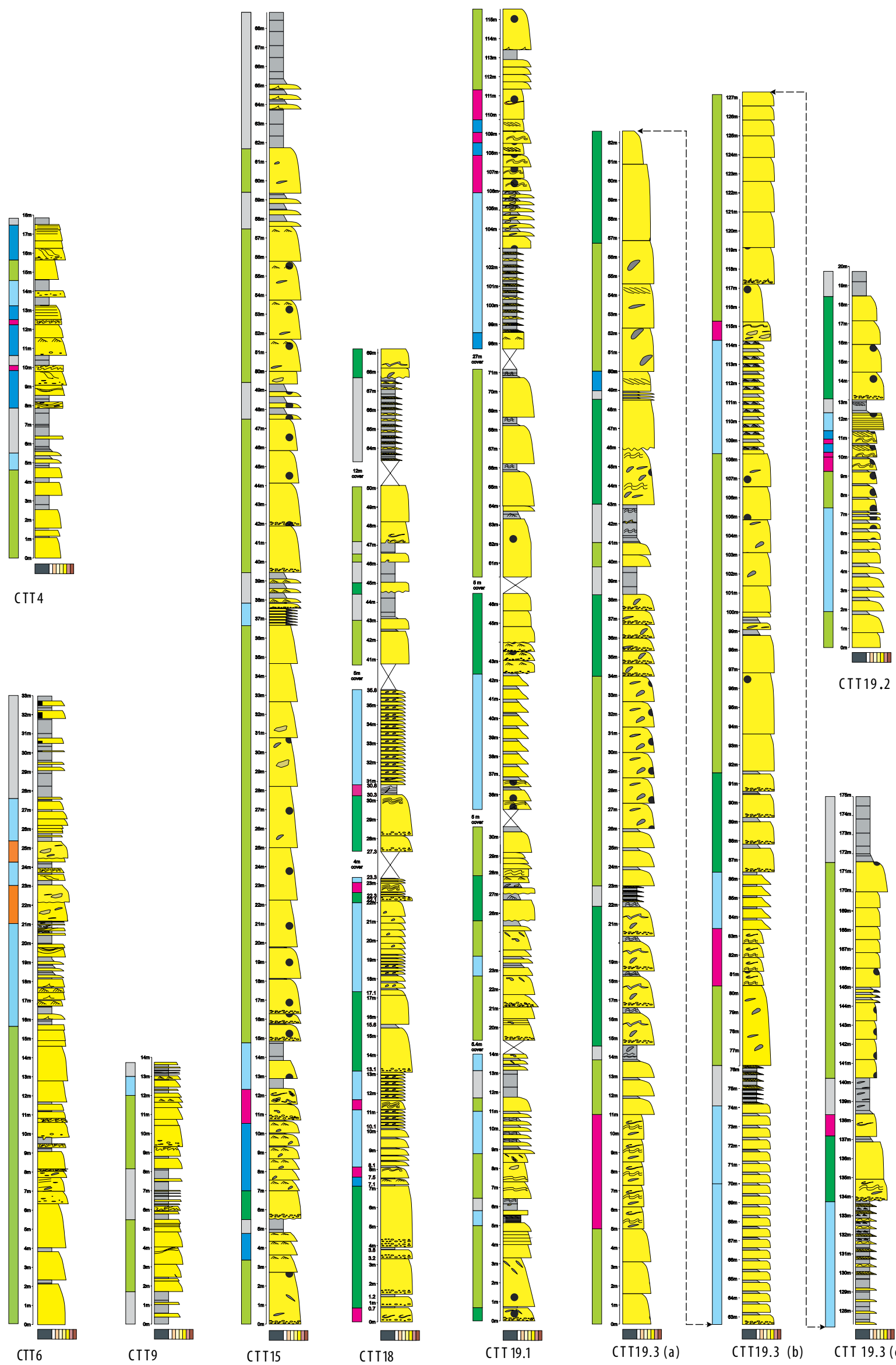

CTT19.2 


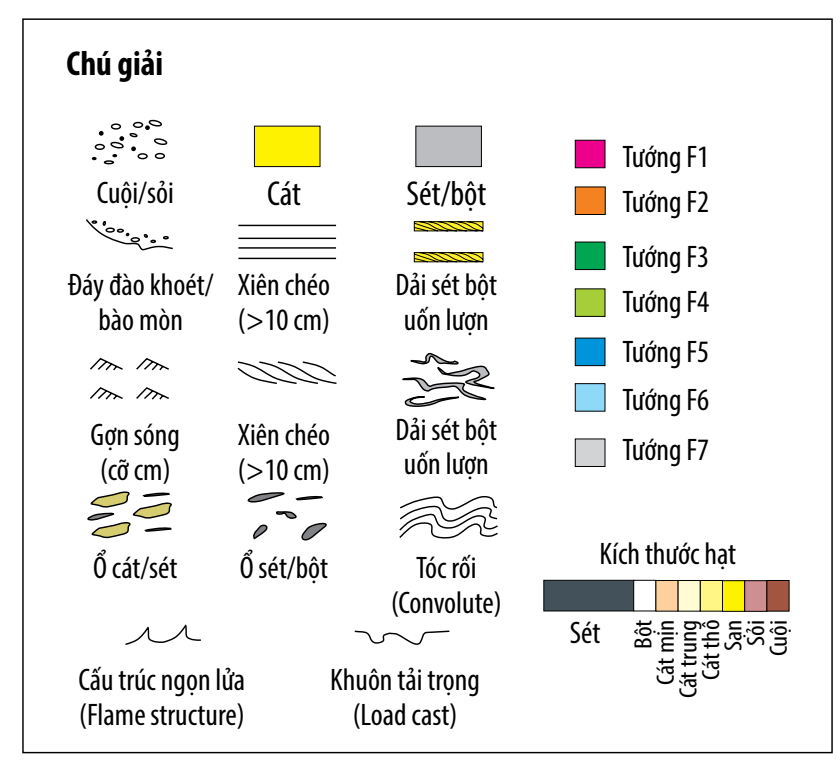

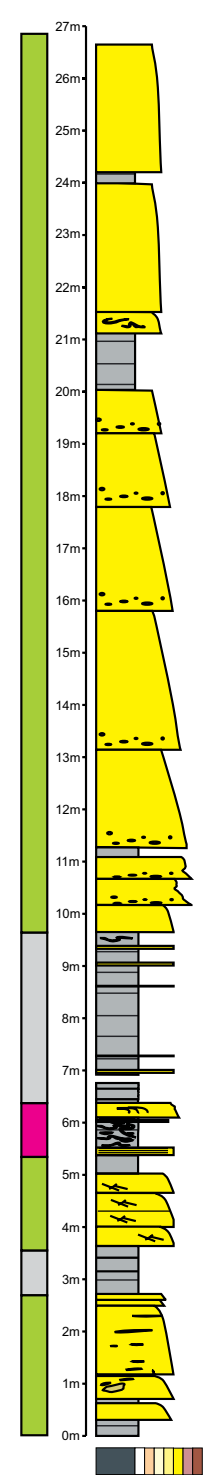

CTC 1

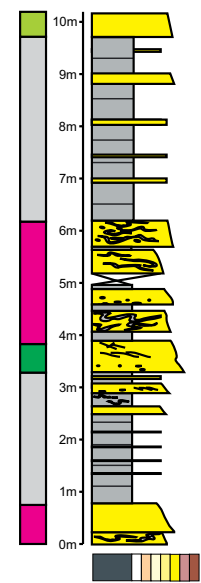

CTC2

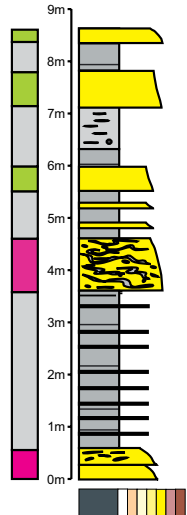

CTC3

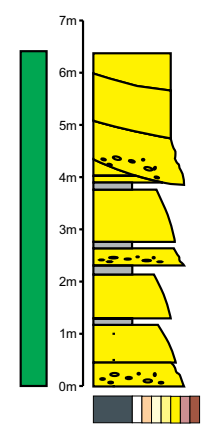

CTC 4

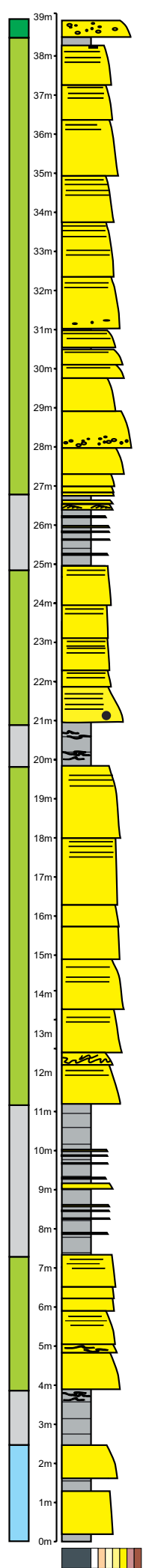

CTC 7.1

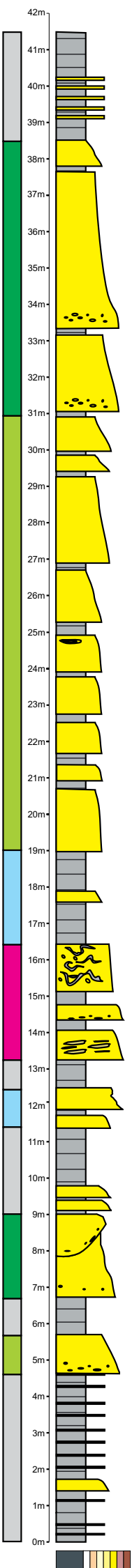

TL 1

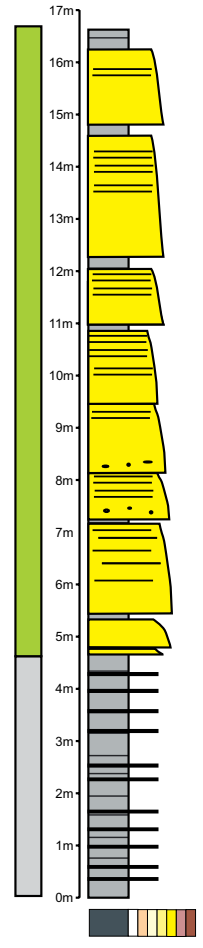

TL 7

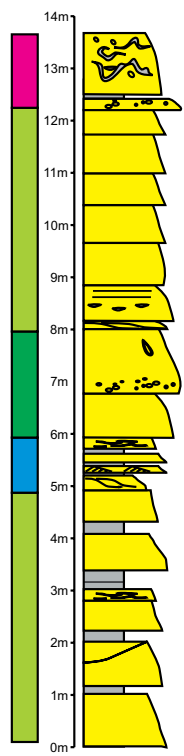

पाIIII

TL 8.1

Hinh 4. Côt đia tâng thach hoc và tướng trầm tích được xây dưng tai mỗi điểm lô trên đảo Cô Tô và Thanh Lân. 


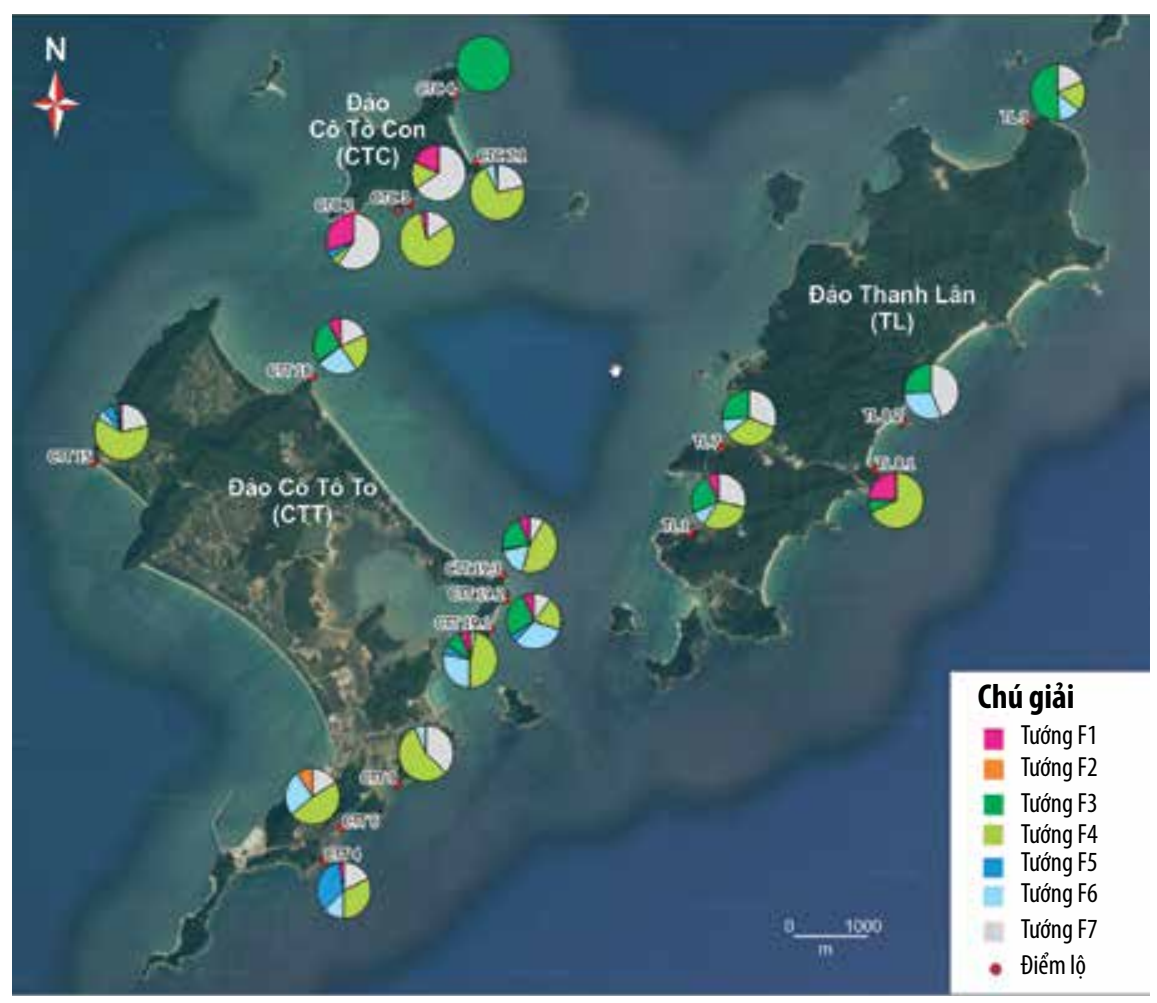

Hình 5. Bản đồ phân bố tướng thạch học tại một số điểm khảo sát trên đảo Cô Tô và đảo Thanh Lân.

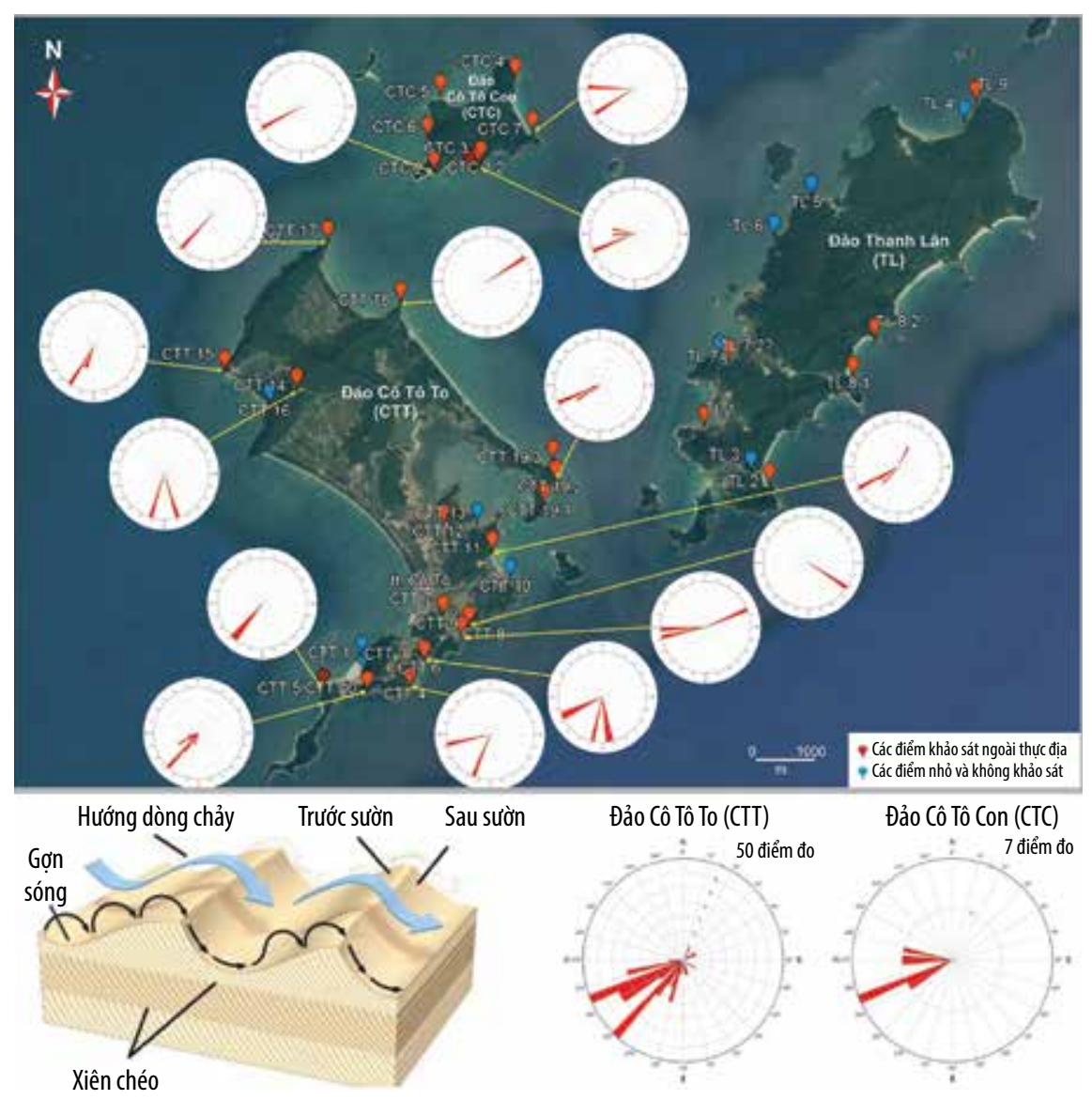

Hình 6. Hướng trầm tích biểu kiến đo tại các cấu trúc xiên chéo và gọnn sóng trên đảo Cô Tô, phản ánh hướng vận chuyển trầm tích. phần trong của quạt giữa dẫn tới sự xuất hiện của cấu trúc tóc rối hoặc hỗn độn trong nhóm tướng này.

- FA4 - nhóm tướng quạt dưới (outer fan)

Nhóm tướng FA4 đặc trưng bởi sự xuất hiện phổ biến của trầm tích sét bột, bột sét phân lớp mỏng dạng sọc dải xen các lớp cát hạt trung đến hạt mịn của tướng F7. Phần giữa và phần trong của quạt ngoài có thể bắt gặp phổ biến các tướng F6. Nhóm tướng FA4 phổ biến là các cấu trúc gợn sóng thoải, đôi chỗ gặp các dạng tóc rối và biến dạng trầm tích mềm (soft sediment deformation). Các mảnh trầm tích ngoại lai với kích thước nhỏ vẫn có thể quan sát được trong nhóm tướng FA4 nhưng ít phổ biến hơn. Nhóm tướng FA4 đặc trưng cho môi trường quạt ngoài của các thành tạo trầm tích turbidite. Cơ chế vận chuyển chính là dòng turbidite xa nguồn, năng lượng dòng chảy thấp và nhiều nơi chỉ chịu ảnh hưởng hoạt động lắng đọng trầm tích biển sâu lơ lửng trong cột nước biển nên thành phần trầm tích hạt mịn chiếm ưu thế (sét bột phân lớp mỏng) [18].

\subsection{Mô hình phân bố tướng và môi trường trầm tích}

Dựa vào các phân tích tướng/ nhóm tướng môi trường và đo vẽ các cột địa tầng tại các điểm khảo sát trên đảo Cô Tô và đảo Thanh Lân, nhóm tác giả đã lập biểu đồ phân bố tướng thạch học cho từng điểm lộ (Hình 5). Từ biểu đồ này kết hợp với hướng trầm tích biểu kiến (Hình 6) đo trên cấu trúc xiên chéo và gợn sóng, đã xác định được phạm vi phân bố môi trường liên quan đến các thành tạo trầm tích turbidite cho khu vực nghiên cứu như sau:

- Nhóm tướng FA1 đặc trưng 
cho hoạt động trượt lở trên sườn thềm và các tích tụ trầm tích nằm ngay chân sườn và phân bố trong khu vực nghiên cứu thuộc đảo Cô Tô Con;

- Nhóm tướng FA2 đặc trưng cho các hệ thống kênh dẫn và trầm tích thuộc phần quạt trên, phân bố chủ yếu ở khu vực đảo Thanh Lân và rìa phía Đông đảo Cô Tô To (CTT 18, CTT 19);

- Nhóm tướng FA3 với sự xuất hiện của các đào khoét và tập cát sạn lẫn cuội, đặc trưng cho hệ thống kênh dẫn. Kết hợp với sự xuất hiện các thấu kính cát, cát phân lớp dày và đôi chỗ xen các lớp sét/bột mỏng cho thấy sự có mặt của các trầm tích tràn bờ trong môi trường quạt giữa. Nhóm tướng $\mathrm{FA3}$ phân bố

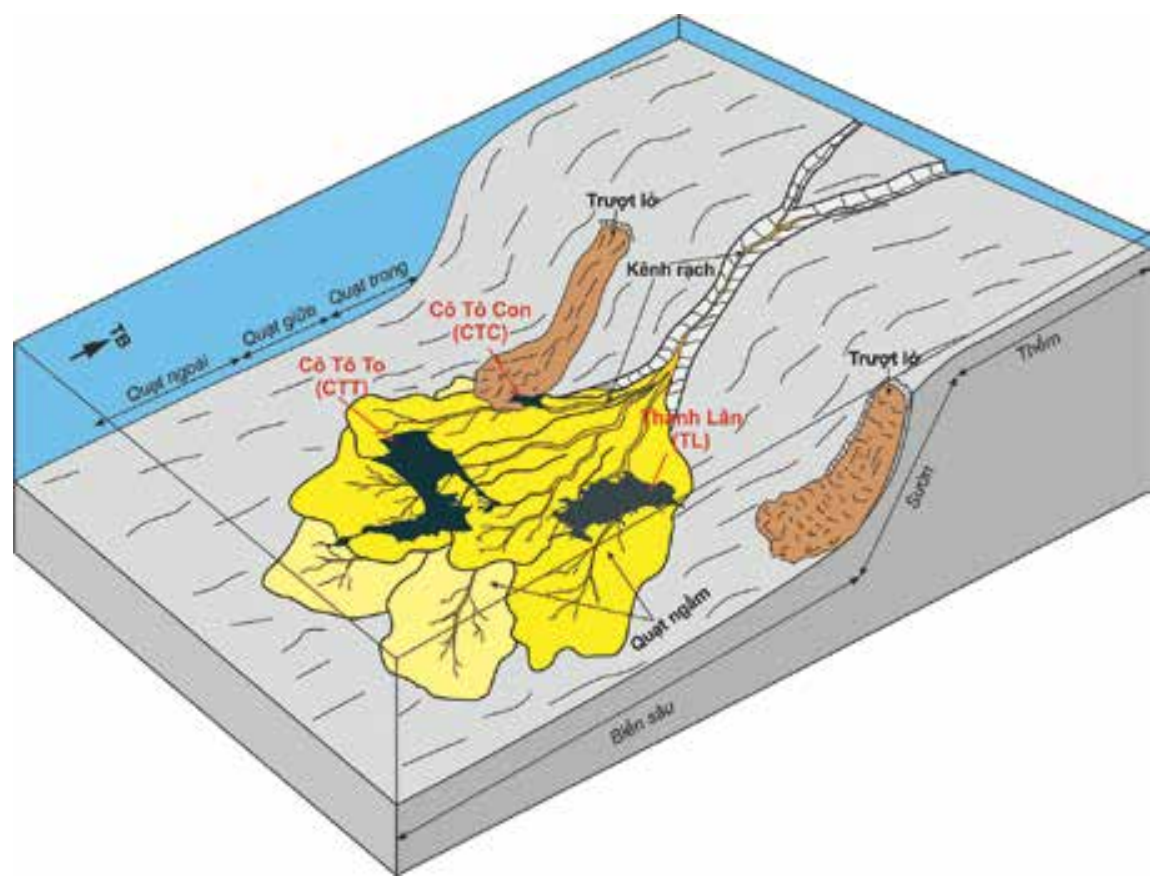

Hình 7. Mô hình phân bố các quạt ngầm và hướng cung cấp vật liệu trầm tích của các thành tạo trâm tích turbidite trên đảo Cô Tô và đảo Thanh Lân. chủ yếu ở phần Tây Nam đảo Thanh Lân (TL 8.1), phía Nam đảo Cô Tô Con (CTC 7.1, CTC 1) và một số nơi trên đảo Cô Tô To;

- Nhóm tướng FA4 đặc trưng cho trầm tích hạt mịn chiếm ưu thế, phân lớp mỏng song song và có sự xuất hiện nhiều các vi cấu trúc bên trong các lớp trầm tích (Bảng 2), thường được thành tạo trong môi trường quạt ngoài. Trong khu vực nghiên cứu, nhóm tướng FA4 phân bố ở phía Nam đảo Thanh Lân (TL1, TL 7, TL 8.2) và phía Tây đảo Cô Tô To (CTT 4, CTT 6, CTT 9, CTT 15).

Nhìn chung trầm tích có xu thế mịn dần từ đảo Thanh Lân sang đảo Cô Tô To, chuyển từ các nhóm tướng $F A 2$ và $F A 3$ (quạt trong - giữa) sang các nhóm tướng $F A 3$ và $F A 4$ (quạt giữa - ngoài), cho thấy hướng chính cung cấp vật liệu trầm tích theo hướng Đông Bắc - Tây Nam. Hướng cung cấp vật liệu trầm tích này cũng khá trùng khớp với hướng đổ trầm tích biểu kiến xác định từ cấu trúc gợn sóng và xiên chéo quan sát được trên đảo Cô Tô (Hình 6). Thông qua các đặc trưng về trầm tích, thạch học, phân loại tướng và

Bảng 2. Bảng tổng hợp và so sánh đặc điểm thạch học và cấu trúc trâm tích turbidite trên đảo Cô Tô và đảo Thanh Lân

\begin{tabular}{|c|c|c|c|c|c|c|c|c|c|c|c|c|c|c|c|c|c|c|c|c|c|c|c|c|c|c|c|c|c|c|c|c|c|c|c|c|c|}
\hline \multirow[b]{3}{*}{$\begin{array}{l}\text { Đặc } \\
\text { điểm } \\
\text { trầm } \\
\text { tích }\end{array}$} & \multicolumn{8}{|c|}{ Cõ hạt/ Thạch học } & \multicolumn{23}{|c|}{ Cấu trúc trầm tích } & \multirow{2}{*}{\multicolumn{6}{|c|}{ Tướng trầm tích }} \\
\hline & & & & & Cát & & & & \multicolumn{14}{|c|}{ Cấu trúc lớn } & \multicolumn{9}{|c|}{ Vi cấu trúc } & & & & & & \\
\hline & 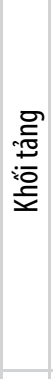 & '응. & స్心. & $\stackrel{\circ}{\models}$ & 全 & 高 & 范 & 芯 & 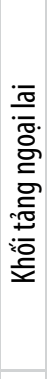 & 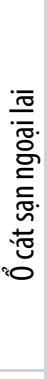 & 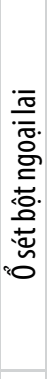 & 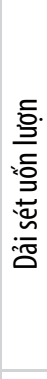 & 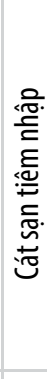 & 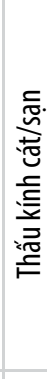 & 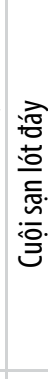 & 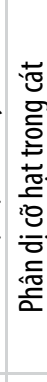 & 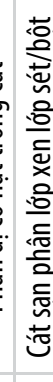 & . & 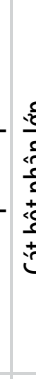 & 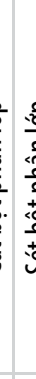 & & 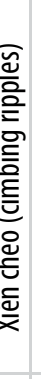 & 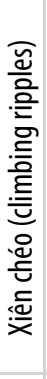 & 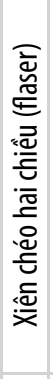 & 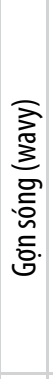 & 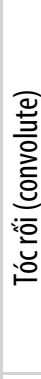 & 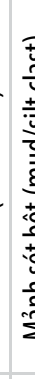 & 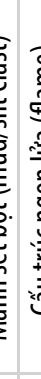 & 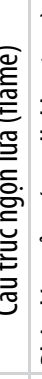 & 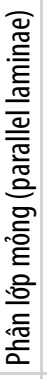 & 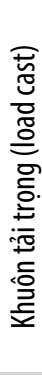 & & & F3 & & F5 F & F6 F \\
\hline Cô Tô To & - & - & - & + & + & + & + & + & + & + & + & + & - & - & + & + & + & + & + & - & & + & + & 0 & + & + & + & - & - & + & 0 & 0 & - & - & + & + & + \\
\hline $\begin{array}{l}\text { Cô Tô } \\
\text { Con }\end{array}$ & - & + & + & + & + & + & + & + & - & + & - & + & 0 & + & + & + & - & + & $t$ & - & & + & + & + & - & + & + & & 0 & + & + & + & + & - & - & 0 & - \\
\hline $\begin{array}{c}\text { Thanh } \\
\text { Lân }\end{array}$ & 0 & + & + & + & + & + & + & + & 0 & - & + & + & 0 & + & + & + & - & + & $t$ & - & & + & + & 0 & + & - & $t$ & - & & + & - & 0 & 0 & . & + & + & - \\
\hline
\end{tabular}

+ Phổ biến; - Hiếm; o Không 
nhóm tướng kết hợp với đo hướng trầm tích biểu kiến từ cấu trúc xiên chéo và gợn sóng, mô hình môi trường lắng đọng trầm tích turbidite liên quan đến đảo Cô Tô và Thanh Lân được xác định như Hình 7.

\section{Kết luận}

Các thành tạo trầm tích turbidite trên đảo Cô Tô và đảo Thanh Lân được phân loại thành 7 tướng trầm tích thay đổi từ $F 1$ đến $F 7$ liên quan đến 4 nhóm tướng môi trường trầm tích turbidite của trầm tích biển sâu và phân bố trên các đảo như sau: (1) Trên đảo Cô Tô Con bắt gặp nhóm tướng FA1 và một phần của nhóm tướng FA2 đặc trưng cho môi trường sườn thềm và phần trong của quạt; (2) Nhóm tướng FA3 quan sát phổ biến trên đảo Thanh Lân, đặc trưng cho các thành tạo trầm tích thuộc phần quạt giữa. Phía Bắc của đảo Thanh Lân có một vài điểm lộ ra nhóm tướng FA2 liên quan đến môi trường chuyển tiếp giữa quạt trong và quạt giữa; (3) Trên đảo Cô Tô To chủ yếu quan sát được các tướng trầm tích tương ứng với nhóm tướng FA4 của quạt ngoài turbidite và một phần nhóm tướng $\mathrm{FA} 3$ của phần quạt giữa với sự xuất hiện của các đào khoét. Các thành tạo trầm tích thuộc quần đảo Cô Tô có hướng cung cấp vật liệu trầm tích phát triển theo hướng Đông Bắc - Tây Nam và trầm tích có xu thế mịn dần từ đảo Thanh Lân và Cô Tô Con sang đảo Cô Tô To, chuyển từ các nhóm tướng FA1, FA2 và $F A 3$ (quạt trong - giữa) sang các nhóm tướng $F A 3$ và FA4 (quạt giữa - ngoài).

\section{Tài liệu tham khảo}

[1] Paul Weimer and Martin H. Link, Seismic facies and sedimentary processes of submarine fans and turbidite systems. Springer New York, 1991. DOI: 10.1007/978-14684-8276-8.

[2] William McCaffrey and Benjamin Kneller, "Process controls on the development of stratigraphic trap potential on the margins of confined turbidite systems and aids to reservoir evaluation", AAPG Bulletin, Vol. 85, No. 6, pp. 971 - 988, 2001. DOI: 10.1306/8626CA41-173B11D7-8645000102C1865D.

[3] Carlos H.L. Bruhn and Roger G. Walker, "Internal architecture and sedimentary evolution of coarse-grained, turbidite channel-levee complexes, Early Eocene Regência Canyon, Espírito Santo basin, Brazil", Sedimentology, Vol. 44, No. 1, pp. 17 - 46, 1997. DOI: 10.1111/j.1365-3091.1997. tb00422.x.

[4] Trần Văn Trị và Nguyễn Đình Uy, Trâm tích Silur-
Devon ở rìa Tây Bắc vịnh Bắc Bộ và điêu kiện thành tạo chúng. Nhà xuất bản Khoa học và Kỹ thuật, 1977.

[5] Đặng Trần Huyên và nnk, "Địa tâng các trâm tích Phanerozoi ở Đông Bắc Bộ", Viện Khoa học Địa chất và Khoáng sản, 2007.

[6] Nguyễn Xuân Khiển, "Báo cáo trầm tích luận và tướng đá, cổ địa lý các thành tạo trầm tích màu đỏ tuổi JuraCreta và khoáng sản liên quan ở miền Bắc Việt Nam", Viện Khoa học Địa chất và Khoáng sản, 2003.

[7] Trần Văn Trị và Vũ Khúc, Địa chất và tài nguyên Việt Nam. Nhà xuất bản Khoa học Tự nhiên và Công nghệ, 2011.

[8] Đặng Mỹ Cung, "Đặc điểm thạch luận thành tạo turbidite hệ tâng Cô Tô (O-Sct) và ý nghĩa địa động lực của chúng", Luận án Tiến sĩ Địa chất, Viện Khoa học Địa chất và Khoáng sản, 2013.

[9] Tống Duy Thanh và Vũ Khúc, Các phân vị địa tâng Việt Nam. Nhà xuất bản Đại học Quốc gia Hà Nội, 2005.

[10] A.E. Dovjikov, "Địa chất miền Bắc Việt Nam - Bản thuyết minh cho Bản đồ địa chất miên Bắc Việt Nam", 1965.

[11] Trần Văn Trị, Nguyễn Đình Uy, Trần Đình Nhân và Đỗ Tuyết, "Tài liệu mới về cấu tạo địa chất quần đảo Cô Tô", Tạp chí Địa chất, Số 105, trang 1 - 4, 1972.

[12] T.D. Thanh, T.H. Phuong, P. Janvier, N.H. Hung, N.T.T. Cuc, and N.T. Duong, "Silurian and Devonian in Vietnam - Stratigraphy and facies", Journal of Geodynamics, Vol. 69, pp. 165 - 185, 2013. DOI: 10.1016/j.jog.2011.10.001.

[13] Muhammad Aqqid Saparin, Mark Williams, Jan Zalasiewicz, Toshifumi Komatsu, Adrian Rushton, Hung Dinh Doan, Ha Thai Trinh, Hung Ba Nguyen, Minh Trung Nguyen, and Thijs R.A. Vandenbroucke, "Graptolites from silurian (Llandovery Series) sedimentary deposits attributed to a forearc setting, Co To formation, Co To archipelago, Northeast Vietnam", Paleontological Research, Vol. 24, No. 1, pp. 26 - 40, 2020. DOI: 10.2517/2019PR003.

[14] Nguyễn Xuân Tùng và Trần Văn Trị, Thành hệ địa chất và địa động lực Việt Nam. Nhà xuất bản Khoa học Kỹ thuật, 1992.

[15] R.L. Folk, Petrology of sedimentary rocks. Hemphill Publishing Company, 1980.

[16] Gary Nichols, Sedimentology and stratigraphy ( $2^{\text {nd }}$ edition). Wiley-Blackwell, 2009.

[17] Emiliano Mutti and Ricci Lucchi, "Turbidites of 
the Northern Apennines: Introduction to facies analysis", International Geology Review, Vol. 20, No. 2, pp. 125 - 166, 1978.

[18] Emiliano Mutti, Turbidite sandstones. Agip, Istituto di Geologia, Università di Parma, 1992.

[19] G. Shanmugam, L.R. Lehtonen, T. Straume, S.E. Syvertsen, R.J. Hodgkinson, and M. Skibeli, "Slump and debris-flow dominated upper slope facies in the Cretaceous of the Norwegian and Northern North Seas $\left(61^{\circ}-67^{\circ} \mathrm{N}\right)$ : Implications for sand distribution", AAPG Bulletin, Vol. 78, No. 6, pp. 910 - 937, 1994.

[20] G. Shanmugam and R.J. Moiola, "Submarine fans: Characteristics, models, classification, and reservoir potential", Earth-Science Reviews, Vol. 24, No. 6, pp. 383 428, 1988. DOI: 10.1016/0012-8252(88)90064-5.

\title{
TURBIDITE FACIES OF CO TO ARCHIPELAGO, NORTHEAST VIETNAM
}

\author{
Nguyen Van Kieu',2, Bui Viet Dung', Bui Huy Hoang', Nguyen Quang Tuan' \\ 'Vietnam Petroleum Institute \\ ${ }^{2}$ AGH University of Science and Technology, Poland \\ Email: van@agh.edu.pl
}

\section{Summary}

The paper presents a detailed facies analysis of the turbidite system of $\mathrm{C}_{0} \mathrm{~T}$ formation in the Co To archipelago including the islands of Big Co To, Small Co To and Thanh Lan. Based on the analysis of sediment bedding, sediment structure and grain-sized trends, 7 sedimentary facies are recognised as a record of the principal modes of sediment deposition. The results show that the recurring development of sedimentary facies within the turbidite system in the Co To archipelago can be grouped into distinct facies associations (FA): slope with channels and slump deposit (FA1), basin floor fans with the common occurrence of inner fan-channel complex (FA2), middle-fan lobes (FA3) and outer-fan distal lobes (FA4). These facies associations represent the turbidite system with the extensive development of NE-SW submarine fan, along the islands of Thanh Lan, Small Co To and Big Co To.

Key words: Turbidite facies, deep- marine deposits, submarine fan, Co To archipelago, Thanh Lan island. 